\title{
Pemberian Tepung Temulawak yang Dicampur dalam Pakan terhadap Perubahan Tinggi Vili Jejenum Ayam Pedaging
}

\section{(FEEDING OF TEMULAWAK FLOUR MIXED IN FOOD TO THE HEIGHT VILI CHANGES OF BROILER JEJENUM)}

\author{
I Gede Ari Krisna ${ }^{1 *}$, Ida Bagus Komang Ardana ${ }^{2}$, Putu Suastika ${ }^{3}$ \\ ${ }^{1}$ Mahasiswa Program Profesi Dokter Hewan, Fakultas Kedokteran Hewan, Universitas \\ Udayana, Jln. PB. Sudirman Denpasar Bali; \\ ${ }^{2}$ Laboratorium Patologi Klinik Fakultas Kedokteran Hewan Universitas Udayana, Jln. PB. \\ Sudirman Denpasar Bali; \\ ${ }^{3}$ Laboratorium Histologi Fakultas Kedokteran Hewan Universitas Udayana, Jln. PB. Sudirman, \\ Denpasar, Bali. \\ *Email: arikrisna84@gmail.com
}

\begin{abstract}
Abstrak
Ayam pedaging memiliki daya produktivitas yang tinggi dalam produksi daging ayam. Semakin tinggi villi usus halus, semakin besar efektifitas penyerapan sari-sari makanan melalui epitel usus halus. Zat gizi yang terkandung dalam temulawak adalah kurkuminoid, mineral, minyak atsiri, minyak lemak, karbohidrat, dan protein. Penelitian ini bertujuan untuk mengetahui perbedaan perubahan tinggi vili jejenum ayam pedaging akibat pemberian tepung temulawak (Curcuma xanthorrhiza Roxb.) dalam beberapa dosis dalam pakan. Sampel penelitian ini menggunakan 40 ayam pedaging jantan umur 14 hari dengan berat rata-rata $420 \mathrm{~g}$ bersamaan dibagi menjadi 4 perlakuan terdiri atas 10 ulangan. $\mathrm{P} 0$ adalah ayam pedaging sebagai kontrol tanpa diberikan tepung temulawak dan hanya diberikan pakan saja. P1 adalah ayam pedaging yang diberikan tepung temulawak sebanyak $10 \mathrm{~g} / \mathrm{kg}$ pakan dengan mencampurkan kedalam pakan. P2 adalah ayam pedaging yang diberikan tepung temulawak sebanyak $20 \mathrm{~g} / \mathrm{kg}$ pakan dengan mencampurkan kedalam pakan. P3 adalah ayam pedaging yang diberikan tepung temulawak sebanyak $30 \mathrm{~g} / \mathrm{kg}$ pakan dengan mencampurkan kedalam pakan, pada hari ke-35 ayam pedaging di nekropsi dan di ambil organ jejenum. Hasil analisis menunjukkan bahwa perlakuan P2 dan P3 tidak berpengaruh nyata $(\mathrm{P}>0,05)$ terhadap kontrol $(\mathrm{P} 0)$, akan tetapi $\mathrm{P} 1$ berbeda nyata $(\mathrm{P}<0,05)$ terhadap $\mathrm{P} 0$, $\mathrm{P} 2$ dan P3, pada perlakuan P2 tidak berbeda nyata $(\mathrm{P}>0,05)$ dengan P3. Simpulan penelitian ini menunjukkan bahwa pemberian tepung temulawak sebanyak $10 \mathrm{~g} / \mathrm{kg}$ pakan, mampu meningkatkan tinggi vili jejenum ayam pedaging.
\end{abstract}

Kata kunci: Jejenum; ayam pedaging; tepung temulawak.

\begin{abstract}
Broiler has high productivity in chicken meat production. The higher the small intestine villi, much greater the effectiveness of the absorption of food extracts through the small intestine epithelium. Nutrients contained in ginger are curcuminoids, minerals, essential oils, fatty oils, carbohydrates, and proteins. This study aims to determine the differences in changes in the height of broiler jejunum villi due to the administration of Curcuma xanthorrhiza Roxb. In several doses in the feed. Samples of this study were 40 male broilers aged 14 days with an average weight of $420 \mathrm{~g}$ simultaneously divided into 4 treatments consisting of 10 replications. P0 is broiler as a control without being given curcuma flour and only given feed. P1 is broiler which is given $10 \mathrm{~g} / \mathrm{kg}$ of curcuma powder by mixing it into the feed. P2 is broiler which is given $20 \mathrm{~g} / \mathrm{kg}$ of temulawak flour by mixing it into the feed. P3 is broiler which is given $30 \mathrm{~g} / \mathrm{kg}$ of temulawak flour by mixing it into feed, on the day 35 broilers then necropsied and taken by jejunum organ. The results of the analysis showed that the treatment of P2 and P3 had no significant effect $(\mathrm{P}>0.05)$ on the control $(\mathrm{P} 0)$, but $\mathrm{P} 1$ was significantly different $(\mathrm{P}<0.05)$ on $\mathrm{P} 0, \mathrm{P} 2$, and $\mathrm{P} 3$, in $\mathrm{P} 2$ treatment, was not significantly different $(\mathrm{P}>0.05)$ with $\mathrm{P} 3$. The conclusions of this study indicate that the administration of curcuma flour as much as $10 \mathrm{~g} / \mathrm{kg}$ of feed, is able to increase the height of jejenal villi in broilers.
\end{abstract}

Keywords: Jejenum; broiler; temulawak flour. 


\section{PENDAHULUAN}

Ayam pedaging mempunyai sifat genetik yang baik dalam pertumbuhan, tetapi sangat rentan terhadap penyakit yang diakibatkan oleh mikroorganisme yang mengganggu kesehatan usus yang menyebabkan perlambatan pertumbuhan (Rahayu et al., 2019). Untuk mengatasi masalah tersebut peternak mengambil tindakan untuk memberikan suplemen yang umumnya dicampur dalam pakan (El-Husseiny et al., 2008). Salah satu tujuan dari pemberian suplemen pakan yaitu untuk menekan populasi mikrooganisme patogen dalam usus serta untuk meningkatkan pertumbuhan (Jin et al., 1997).

Pemberian antibiotik dalam pakan dahulu banyak dilakukan, tetapi dapat menimbulkan masalah baru, dimana munculnya bakteri-bakteri yang resisten terhadap antibiotic (Chattopadhyay, 2014). Residu antibiotik dalam daging ayam, dapat membahayakan konsumen. Keadaan ini dapat menyebabkan mingrooganisme menjadi resisten dalam tubuh ternak (Daud, 2005). Penggunaan bahan lain dalam peternakan unggas banyak disarankan untuk mengganti antibiotik dalam mencegah terjadinya bahaya residu antibiotik dalam daging.

Penggunaan bahan organik kemudian menjadi alternatif sebagai suplemen pakan ternak. Salah satunya adalah temulawak (Curcuma xanthorrhiza Roxb). Temulawak merupakan jenis tanaman obat yang potensial untuk dikembangkan, dan merupakan jenis tanaman unggulan dari Ditjen POM yang memiliki banyak manfaat sebagai bahan obat. Pemanfaatan tanaman ini cukup banyak, antara lain dipergunakan oleh masyarakat dalam pemeliharaan dan peningkatan derajat kesehatan atau pengobatan penyakit maupun oleh produsen obat tradisional dan kosmetika (Nurjanah $e t$ al., 1994).

Selain penggunaannya sebagai bahan baku industri seperti minuman dan pewarna alami, manfaat lain adalah dapat meningkatkan sistem imunitas tubuh, berkhasiat antibakteri, antidiabetik, antihepatotoksik, antiinflamasi, antioksidan, antitumor, diuretika, depresan dan hipolipodemik (Purnomowati dan Yoganinggrum, 1997; Raharjo dan Rostiana, 2003). Bagian yang berkhasiat dari temulawak adalah rimpangnya yang mengandung berbagai komponen kimia di antaranya zat kuning kurkumin, protein, pati dan minyak atsiri. Salah satu komponen terbesar temulawak sering disebut sebagai pati yang mudah dicerna.Minyak atsirinya mengandung senyawa phelandren, kamfer, borneol, sineal, xanthorhizol. Kandungan xanthorizol dan kurkumin ini yang menyebabkan temulawak sangat berkhasiat (Taryono et al., 1987)

Belum ada laporan mengenai pengaruh suplemen tepung temulawak terhadap tinggi vili usus halus khususnya pada jejenum ayam pedaging. Oleh karena itu penelitian ini perlu dilakukan untuk mengetahui pengaruh pemberian tepung temulawak terhadap perkembangan usus halus terutama jejenum pada ayam pedaging.

\section{METODE PENELITIAN}

\section{Sampel}

Sampel penelitian ini menggunakan 40 ayam pedaging jantan umur 14 hari dengan berat rata-rata $420 \mathrm{~g}$ bersamaan dibagi menjadi 4 perlakuan terdiri atas 10 ulangan.

\section{Perlakuan sampel}

Ayam pedaging yang digunakan sebelum diberi perlakuan diadaptasi selama dua minggu sebelum dipisahkan untuk percobaan. Setelah umur 14 hari ayam pedaging dipisahkan pada 4 kandang terpisah berisi sekam, pakan dan air minum. Masingmasing kandang berisi 10 ekor ayam pedaging sehingga total keseluruhan 40 ayam. Ayam pedaging dibagi atas 4 perlakuan yaitu kelompok P0, P1, P2, P3. Pemberian tepung temulawak dicampur pada pakam dengan dosis bertingkat pada tiap-tiap perlakuan setiap hari sampai hari ke-35 (21 hari), pada hari ke-35 setelah perlakuan di nekropsi dan di ambil organ jejenumnya. 


\section{Pemeriksaan jaringan jejenum}

Pengambilan sampel jaringan jejenum untuk dibuat preparat histologi difiksasi dalam larutan NBF 10\% agar jaringan tidak mengalami autolysis.

\section{HASIL DAN PEMBAHASAN}

Pemberian tepung temulawak yang dicampur dalam pakan pada hari ke 14 sampai hari ke 35 menunjukkan adanya pengaruh terhadap perubahan tinggi vili jejenum. Hasil uji duncan tinggi vili jejenum ayam pedaging pada semua kelompok perlakuan tersaji pada Tabel 1.

Hasil pengukuran tinggi vili jejenum ayam pedaging kontrol diperoleh rerata $1348,4389 \mu \mathrm{m}$, pada P1 yaitu penambahan tepung temulawak sebanyak $10 \mathrm{~g} / \mathrm{kg}$ pakan pada umur 14 hari sampai 35 hari diperoleh rerata tinggi vili jejenum 1923,1186 $\mu \mathrm{m}, \mathrm{P} 2$ yaitu penambahan tepung temulawak sebanyak $20 \mathrm{~g} / \mathrm{kg}$ pakan pada umur 14 hari sampai 35 hari diperoleh rerata tinggi vili jejenum 1338,9896 $\mu \mathrm{m}$, dan P3 yaitu penambahan tepung temulawak sebanyak 30 $\mathrm{g} / \mathrm{kg}$ pakan pada umur 14 hari sampai 35 hari diperoleh rerata tinggi vili jejenum $1420,1477 \mu \mathrm{m}$. Gambaran tinggi vili jejenum ayam kontrol, P1, P2, dan P3 dapat dilihat pada Gambar 1.

Tabel 1. Hasil uji duncan tinggi vili jejenum ayam pedaging

\begin{tabular}{cccc} 
Perlakuan & $\mathrm{N}$ & \multicolumn{2}{c}{ Subset } \\
\cline { 3 - 4 } P2 & 10 & $1338,9896^{\mathrm{a}}$ & 2 \\
P0 & 10 & $1348,4389^{\mathrm{a}}$ & \\
P3 & 10 & $1420,1477^{\mathrm{a}}$ & \\
P1 & 10 & & $1923,1186^{\mathrm{b}}$ \\
Sig & & 0,164 & 0,000 \\
\hline
\end{tabular}

Ket: Huruf superskrip yang sama menyatakan tidak berbeda nyata pada taraf $\mathrm{P}>0,05$

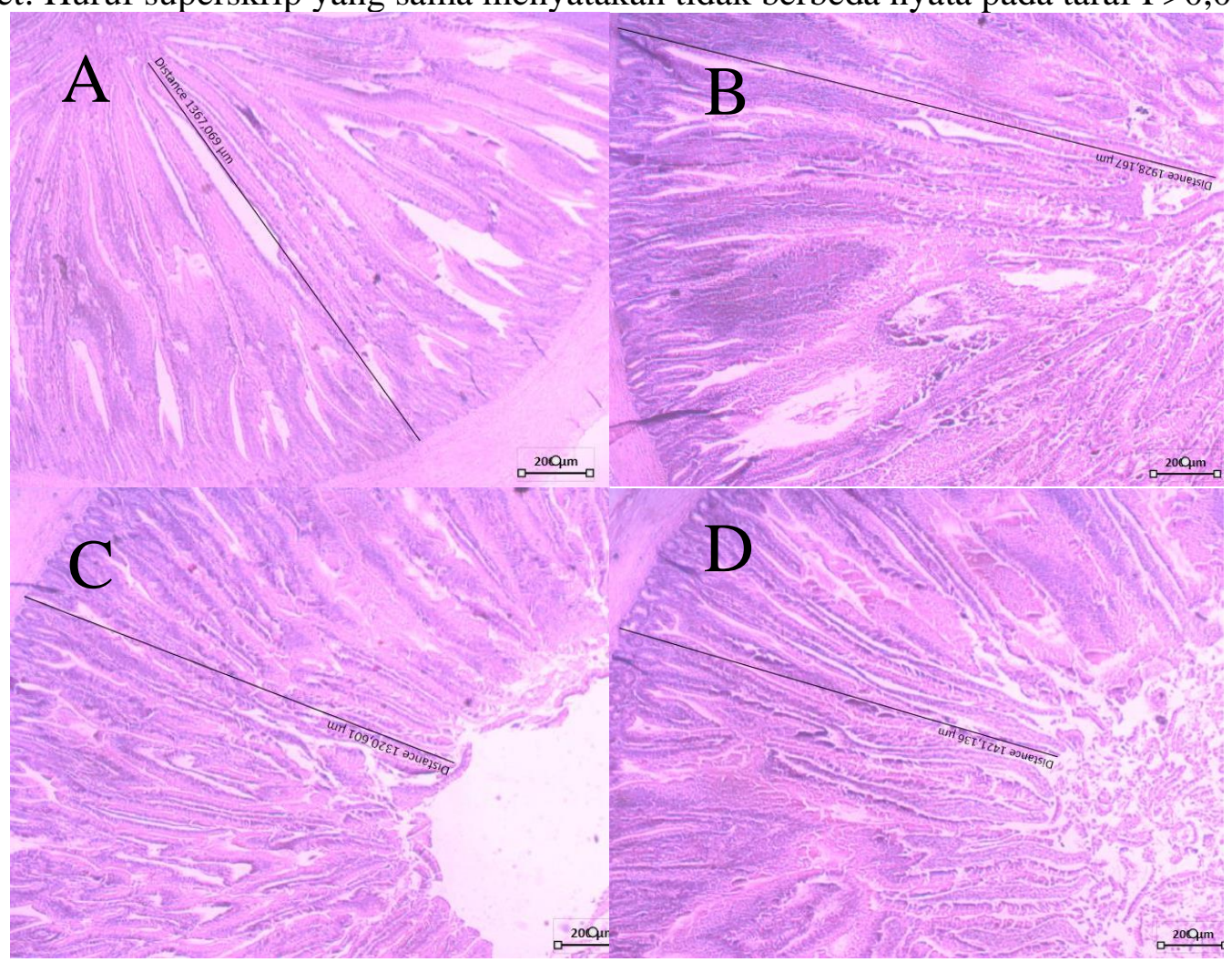

Gambar 1. Pengukuran tinggi vili jejenum ayam pedaging, ( HE, 40X ). Kontrol (P0) (A), P1 (B), P2 (C), dan P3 (D). 
Hasil penelitian ini menunjukkan bahwa penambahan tepung temulawak sebanyak 10 $\mathrm{g} / \mathrm{kg}$ pakan (P1), $20 \mathrm{~g} / \mathrm{kg}$ pakan (P2), $30 \mathrm{~g} / \mathrm{kg}$ pakan (P3), dan kontrol sebanyak $0 \mathrm{~g} / \mathrm{kg}$ pakan (P0) pada pakan pada hari ke 14 sampai hari ke 35 berpengaruh nyata $(\mathrm{P}<0,05)$ terhadap tinggi vili jejenum ayam pedaging. Hasil menunjukkan bahwa penambahan tepung temulawak sebanyak 10 dan $30 \mathrm{~g} / \mathrm{kg}$ pakan pakan memiliki tinggi vili jejenum yang paling panjang dibandingkan dengan kontrol. Sedangkan penambahan tepung temulawak sebanyak $20 \mathrm{~g} / \mathrm{kg}$ pakan memiliki tinggi vili jejenum lebih pendek dibandingkan dengan kontrol.

Pada penelitian ini, peningkatan vili jejenum ayam pedaging dikarenakan kandungan zat gizi dari temulawak. Zat gizi yang terkandung dalam temulawak adalah kurkuminoid, mineral, minyak atsiri, minyak lemak, karbohidrat, dan protein (Kasiran, 2009). Minyak atsiri merupakan senyawa yang dapat meningkatkan produksi getah empedu, dan sebagai antinflamasi. Kandungan kimia minyak atsiri antara lain fellandrean, kamfer, tumerol, tolil metil karbinol, arkurkumen, zingiberen, kuzerenon, germakron, $\beta$-tumeron, serta xanthorrhizol yang menghasilkan hingga 40\% (Rahardjo dan Rostiana, 2004). Selain itu, Temulawak mengandung zat fitokimia yang biasa disebut desmetoksikurkumin dan bisdesmetoksikurkumin sedangkan untuk zat fitokimia kunyit biasa disebut desmetoksikurkumin. Zat - zat fitokimia ini dapat mempengaruhi nafsu makan, meningkatkan sekresi empedu, memperbaiki fungsi hati serta tampilan limfosit darah (Sufriyanto dan Mohandas, 2005). Sedangkan penurunan tinggi vili jejenum terjadi karena adanya faktor internal dari ayam pedaging tersebut. Akan tetapi penurunan tersebut masih tergolong dalam rerata tinggi vili jejenum ayam pedaging normal.

\section{SIMPULAN DAN SARAN}

\section{Simpulan}

Dari hasil penelitian dapat disimpulkan bahwa pemberian tepung temulawak berpengaruh nyata terhadap tinggi vili jejenum ayam pedaging. Hasil menunjukkan bahwa penambahan tepung temulawak sebanyak $10 \mathrm{~g} / \mathrm{kg}$ pakan memiliki tinggi vili jejenum yang paling panjang.

\section{Saran}

Dengan adanya hasil peningkatan tinggi vili jejenum ayam pedaging akibat pemberian tepung temulawak, maka peternak dapat mencampur tepung temulawak kedalam pakan ayam untuk memperoleh penyerapan yang sangat optimal pada pencernaan ayam pedaging.

\section{UCAPAN TERIMAKASIH}

Penulis mengucapkan terimakasih kepada Dekan Fakultas Kedokteran Hewan Universitas Udayana yang telah memfasilitasi pelaksanaan penelitian ini.

\section{DAFTAR PUSTAKA}

Afifudin AN. 2009. Pengaruh pemberian ekstrak etanol temulawak (Curcuma xanthorrhiza Roxb.) pada aktivitas dan kapasitas fagositosis makrofag peritoneal ayam petelur (Gallus Sp.) IPB Repository. Undergraduate Theses. UT Veterinary Clinic Reproduction and Pathology.

Chattopadhyay MK. 2014. Use of antibiotics as feed additives: a burning question. Front. Microbiol., 5(334): 1-3.

Daud M. 2005. Performan ayam pedaging yang diberi probiotik dan prebiotik dalam ransum J. Ilmu Ternak., 5(2): 75-79.

El-Husseiny OM, Abdallah AG, AbdelLatif KO. 2008. The influence of biological feed additives on broiler performance. Int. J. Poult. Sci., 7(9): 862-871.

Jin LZ, Ho YW, Abdullah N, Jalaludin S. 1997. Probiotics in poultry: modes of action. J. World's Poult. Sci., 53: 351368.

Kasiran. 2009. Peningkatan kandungan minyak atsiri temulawak sebagai bahan baku obat. Bul. Penelitian Sistem Kesehatan, 12(1): 49-54. 
Lenhardt L, Mozes S. 2003. Morpho-logical and functional changes of the small intestine in growth-stunted broilers. Acta Vet. Brno., 72: 353-358

Mulyantini NGA. 2010. Ilmu Manajemen Ternak Unggas. Yogjakarta: Gadjah Mada University Press

Purnomowati S, Yoganingrum A. 1997. Temulawak (Curcuma xanthorhiza Raharjo M, Rostiana O. 2003. Standar Prosedur Operasional Budidaya Temulawak. Sirkular No. 8. Badan Penelitian dan Pengembangan Pertanian. Balittro, Bogor. Pp. 33-38.

Rahayu IHS, Darwati S, Mu'is A. 2019. Morfometrik Ayam Broiler dengan Pemeliharaan Intensif dan Akses Free Range di Daerah Tropis. J. Ilmu Prod. Teknol. Hasil Peternakan, 7(2): 75-80.
DOI: 10.24843/bulvet.2020.v12.i02.p04

Murtidjo. 1987. Pedoman Beternak Ayam Broiler. Penerbit Kanisius. Yogyakarta. Nurjanah N, Yuliani S, Sembiring AB. 1994. Temulawak (Curcuma xanthorrhiza). Review Hasil-Hasil Penelitian. Balai Penelitian Tanaman Rempah dan Obat., 10(2): 43-57.

Roxb.). Pusat Dokumentasi dan Informasi Ilmiah, LIPI, Jakarta. Pp. 44.

Taryono EM, Rahmat S, Sardina A. 1987. Plasma nutfah tanaman temu-temuan. Ballittro., 3(1): 47-56.

Sufriyanto, Indradji M. 2005. Efektivitas pemberian ekstrak temulawak (Curcumae xanthoriza) dan kunyit (Curcumae domestica) sebagai immunostimulator flu burung pada ayam niaga pedaging. Anim. Prod., 9(3): 178183. 